\title{
Influence of Henrik Ibsen on the Social Drama of Rachel Crothers
} Hossain MA*

Department of English, IBAIS University, Bangladesh

*Corresponding author: Hossain MA, Department of English, IBAIS University, Bangladesh, Tel: +8801915908306; E-mail: amir.hossain.16578@gmail.com

Received date: Mar 28, 2016; Accepted date: April 22, 2016; Published date: April 28, 2016

Copyright: @ 2016 Hossain MA. This is an open-access article distributed under the terms of the Creative Commons Attribution License, which permits unrestricted use, distribution, and reproduction in any medium, provided the original author and source are credited.

\begin{abstract}
This study attempts to look at having an influence of Henrik on the social drama, Susan and God of Rachel Crothers, where it focuses on social themes and moral problems affecting women, including- sexual double standard, trial marriage, free love, divorce, and prostitution. Crothers gains a reputation as a young dramatist of serious potential with a very keen interest in an Ibsen style, "Social Problem Drama." This study highlights Ibsen as a major 19th century Norwegian playwright, who is often referred to as the "Father of Modern Drama." Today, Ibsen is considered to be the greatest Norwegian author; and is celebrated as a national hero by the Norwegians. However, there was a time when Ibsen was an object of criticism and condemnation not only in his contemporary Norway, but also in the continental Europe, and in the conservative bourgeois society in particular. Moreover, Crothers was an American playwright and theater-director known for her well-crafted plays which deal with the women's questions and social themes. Among theater-historians, she is recognized as the most successful and prolific female dramatist writing in the first part of the 20th century. Anyway, this study aims to expose Ibsen's and Crothers' core philosophy of feminist message as well as social problem. It highlights Ibsen's prose styled plays, including-Ghosts and $A$ Doll's House as a model-play with a view to prioritizing on the dominant discussion of Crothers' play-text, Susan and God. In this regard, it would like to apply the critical comments made by prominent critics and scholars for presenting the influence of Ibsen on the social drama, Susan and God.
\end{abstract}

Keywords: Crothers; Ibsen; Nora helmer; Susan trexel;

\section{Introduction}

Playwrights of two different countries, Norway and the United States of America, with a gap of only a half century, one writing in Norwegian, and the other in English, Henrik Ibsen and Rachel Crothers $[1,2]$ are the leading modern playwrights, investigating the social problem arising out of the marginalization of women in the male dominated 19th century Scandinavia as well as the 20th century America respectively. Their dramatic art exposes an in-depth exploration of familial, social, economic, psychological, and sexual harassment faced by women in everyday life. They have created powerful women characters, including Nora Helmer of $A$ Doll's House, Mrs. Alving of Ghosts, and Susan Trexel of Susan and God to highlight the feminist issues and social themes of the age.

Henrik Ibsen was a major 19th century Norwegian playwright. He is often referred to as the father of modern drama. Today, he is considered to be the greatest Norwegian author and is celebrated as a national hero by the Norwegians. However, there was a time when Ibsen was an object of criticism and condemnation not only in his contemporary Norway, but also in continental Europe, and in conservative bourgeois society in particular. The reason is that Ibsen wanted to emphasize more on social issues: women's question and familial matters, especially bourgeois system and order in some of his major plays with a view to exposing a faithful social picture of his age. Again, Rachel Crothers was an American leading dramatist and theater director known for her well-crafted plays, unveiling the feminist themes and social problems. Among theater historians, Crothers has distinguished herself as one of the most important playwrights in the USA and prolific female dramatist of the early 20th century and as an influential force in the development of the modern drama. She gains a reputation as a young dramatist of serious potential with an interest of Ibsen-style, social problem drama [3].

Both Ibsen and Crothers dramatize many problems faced by women: the conflict between marriage and love; motherhood and profession, unfairness of the double standard; alienation of a single career woman; hollowness of marriage; and opposition faced by the powerful women. They try to bring not only new women to the stage, but also new ground by directing, staging, and casting their plays on the center-stage. Their plays are of importance in the history of the development of social drama in the field of English literature. They represent women in various social problems and with various perspectives of male against female. They reflect social forces which shape women's activities and aspirations, where they are the New Women in search of power, identity, and freedom as an imaginary vehicle of fulfillment to achieve both a sense of self and freedom from the male ego's limited perception. Their female characters are preeminent in merit, intelligence, firmness, and integrity. They have given women vigorous and strong voice through portraying the characters, including- Nora Helmer, Mrs. Alving, and Susan Trexel to highlight superstitious faith, religious orthodox, alienating attitudes, and psychological conflicts.

In this way, this study shows Ibsen's and Crothers' plays in the light of female subjugation, marginalization, and oppression in the bourgeois society. It unveils everyday problems of women, including conflicting senses, dilemma, human rights as well as the suffrage of women for centuries. It makes a thorough study of Ibsen's and Crothers' treatment of women in different phases of life. It examines also their skills in exploring powerful women, both in their individual spheres and in relation to the people around them. Thus, it endeavors to reveal various aspects of women in their literary canon. 
Anyway, this study aims to focus on the influence of Henrik Ibsen on the social drama, Susan and God of Rachel Crothers in the light of social and feminist issues. It also highlights Ibsen's prose styled plays, especially $A$ Doll's House and Ghosts to make a comparative analysis with Crothers' feminist play, Susan and God.

\section{Feminist and Social Influence on A Doll's House}

Henrik Ibsen's play, A Doll's House, is a wonderful document of feminist ideas. Through this play, Ibsen earns popularity and fame as one of the leading playwrights in the history of literature. This text is viewed as one of the most famous plays of Ibsen for his presentation of Nora Helmer who is regarded today as one of the most powerful female characters. However, Ibsen is also criticized for his portrayal of Nora, because he lets Nora leave her little children. Critics find fault in Ibsen that no mother can leave her children; any society cannot accept her departure. He unveils the issue of female power through her character, who is considered as a symbol of the 19th century Scandinavian feminism. In our time, many women are struggling for freedom, right, and power like Nora.

A feminist reading of $A$ Doll's House proposes Nora's allegations against Torvald Helmer due to want of love of Nora, psychological condolence, and affection for her. She is devoid of love and affection from her husband despite living with him for eight years and having borne him three children. Her accusations against Helmer show her bitter attitudes towards him. She never wants to tolerate her familial duty and responsibility. She finds no meaning of life, and understands that her dreams would never be fulfilled. So, she endures all her duties and responsibilities silently. Her conduct rejects any idea like Helmer's casting her in the role of a little skylark and squirrel. From Nora's psychological point of view, the play can be judged in terms of the concept of power in the 19th century when a Norwegian woman was supposed to have achieved her awareness and sensibility. She is conscious of Torvald's judgment of power from an equal sense of power that she does not hurt his conscience. It is out of a mixture of her love and pity for Torvald that she collects finance and does everything required. It is not only Nora's love for Torvald, but also pity by being inverted powerful side.

It is Nora's sense of power that impels her to an open confrontation with Torvald. It is as if Torvald wants to feel power that he cannot bear to be in debt. He would be humiliated if he thought he owned anything to himself which gives her sense of pride or power. Nora takes in her efforts without which Torvald would have never got better. She also claims to have an exceptional "flair for business," which is one kind of a power that a wife can borrow money without her husband's permission. She tries to make Torvald go to the southern part of Italy to save his life. Nora's power originates from her pleasant appearance and youth in particular and from her act of saving her husband's life in general.

Nora saves money what Torvald would give to her. Whenever Torvald gives her money for cloths, she never spends more than half of it. She always buys the simplest and cheapest things for herself. Torvald has never any suspicions in her. She always tries to manage everything carefully. She prefers simple dress for herself. She undergoes to earn more money to pay installments of the loan. She feels herself like a complete man to invent her identity.

What Nora does in Helmer's family is like that a male does in his family. She toils message throughout the year to earn money and to bring a radiant future in her own family. Her sense of happiness leads her to an expectation from life- she wants to have a good fortune. She feels pride for her honest labour. She has been able to solve her economic barrier and complexity. At the same time, she has been able to save her husband's life. She plays a dominant role to solve economic crisis through her hard labour. Thus Ibsen wants to show Nora as an economically solvent woman [4].

Moreover, Nora's power upon Torvald ensures a job for Mrs. Linde in his bank. Mrs. Linde comes to the town after a longtime inquest of life and living. She has got a faith in her own power to secure a job for Mrs. Linde. When Krogstad appears and wants to talk with her for a while, he asks if Mrs. Linde is going to have any post in Torvald's bank. Then Nora replies, "How dare you question me? Mr. Krogstad-one of my husband's subordinates" (Act I, 63). Her subordination does not appear to be objectionable. While indulging in her sense of pride and power about her husband, she says: "If you speak disrespectfully of my husband, I shall show you the way" (Act I, 65). In the name of her husband's respect, it is Nora herself who is now doing the actual subordination. Krogstad and Mrs. Linde express sense of pride and power. Krogstad wants to press Nora over the loan when it is convenient for him and inconvenient for Nora.

When Krogstad threatens Nora, particularly about the 'secret' of her loan, she expresses her sense of pride about Torvald. She is so proud of her secret. She shifts from her sense of pride about the secret of what she has done for Torvald's life. She utters a clear lie to Torvald which makes her more vulnerable before Torvald becomes more forgiving to her. What Torvald tells Nora about Krogstad contains serious implication for Nora in the harmful impact of conduct in her family. Torvald accuses that she has corrupted his children and has poisoned his home. Then, she decides to protest against him on the sly. Before her liberating departure, Nora says what proves to be a different realization with her, and she will have to be changed, "both of us would have to be so changed that - oh, Torvald, I do not believe in miracles any longer" (Act III, 175).

What happens finally gives Nora a false sense of a win over Helmer whenever her power of love is concerned. She suffers from such a clear defeat that she cannot deny or escape. Torvald's own sense of a win over Nora makes him protective about her. She leaves his house and takes an escape only. She deceives herself also. As Torvald goes to check his mail, or read his letters, she tries to prepare herself for suicide. When Torvald tries to hold her back, "struggling to free herself," declares her resolve, "you shan't save me, Torvald." But, a similar response comes over Nora when Dr. Rank declares her strange kind of love for her. Nora abruptly changes and turns cold to the desperate offer of love to her. Now she wants to establish existence and freedom as much as like a man. A little later, Nora tells Dr. Rank something that equates him with the servants of her childhood years. She says something through which she compares Torvald with her father:

Oh, dear kind Dr. Rank, which is not what I meant at all. But, I'm sure you can see that being with Torvald is very like being with Papa (Act II, 110).

Nora cannot accept anyone as equal. And, she cannot accept any help from an equal, either she can look either upward or downward, and can tolerate either the superior or the inferior around her. She wants to build up her own sense of power over Helmer. She has got a more satisfying sense of being Helmer's songbird, etc. that she wants to make for herself. She has a sense of power of collaborating with her sense of beauty about herself to fulfill her innocent dream. Torvald 
tries to reach a compromise at the end of the play. Though she admits some of her faults, she does so with a sense of power, and lays most of the blame on the male authority. She takes an important decision that would affect her innocent children and her family. She takes her crucial decision-Our home has been nothing but a play-room; I've been your doll-wife here, just as at home. I was Papa's doll-child. And, the children have been my dolls in their turn. I liked it when you came and played with me, just as they liked it when I came and played with them. That's what our marriage has been, Torvald (Act III, 164).

Like a woman, Nora has done an equal amount of playing with her children. She does not do the same wrong to her children once her father and husband did against her. She decides to leave the children and family for her self-existence. She herself says that she is equally mistreated. She raises her finger against her husband and father. Her decision is to become self-reliant like a complete human being. In fact, Ibsen wants to make women conscious of their duties and responsibilities for establishing freedom and power through this female character.

In the play, $A$ Doll's House, Ibsen wants to show Torvald Helmer as an immature human being. His sense of power and of direct domination harms his own development as a normal human being. He is found to be a representative of a dominating class. Despite characteristic state of his intellect, he fails to find out the gaps in Nora's accusation against him and her own lapse. Like a coward, he takes all her allegations because of his immature wit and knowledge. Finally, he tries to compromise with Nora as a conjugal unit. Due to mutual domination and insincere effort, Helmer's family becomes empty [4].

To make a comparative study of Ibsen's play, $A$ Doll's House with Crothers' play, Susan and God, this study attempts to evaluate Ibsen's document as a faithful picture of women's domination by men. The play, $A$ Doll's House, is considered as one of the most famous plays due to his portraiture of Nora, through whom Ibsen wants to unveil an image of his contemporary women's position and social reality of the traditional authority, where a woman is viewed as an object of male desire and as an alienated being. It aims to look at Nora's quest for power and her rebellion against the patriarchal society. Ibsen wrote his play, $A$ Doll's House during the period when women were enslaved by their gender roles; certain restrictions were enforced on them by the male dominant society. The play's conclusion makes it clear that while Torvald Helmer objects to divorce Nora's act of alienating herself from the society would be a radical step. Thus, her exodus at the play's conclusion is a brave and dangerous act.

\section{Feminist and Social Effect upon Ghosts}

This study throws light on power and freedom in the play, Ghosts, focusing on love, marriage, sexuality, and women's problems. As a conscious critic of contemporary society, Ibsen aims to show domination and power of the 19th century Norwegian traditional system and order. He highlights a filthy image of his contemporary society by creating male and female characters. In some plays, Ibsen prioritizes women's characters who are devoted to dominating the whole family to regain power and freedom. Mrs. Alving is such a domineering and powerful woman through whom this study would like to determine a difference between the patriarchy and the matriarchy of the 19th century Norway. Social reality and women's problems are reflected in most of Ibsen's plays. The play, Ghosts is one of them. For this purpose, it makes use of the silent struggle for freedom, salvation, and power of a woman from the bondage of the cruel past.

In the play, Ghosts, Ibsen, through different dialogue of Mrs. Alving, unveils the hollowness of certain conventions regarding love, marriage, sexuality, and familial matters. Ibsen dramatizes Mrs. Alving's character that is anxious to preserve the reputed name of a rakish husband by erecting a memorial to him after his death, and unwilling to spend money left by him for her, or any social purpose. On the contrary, a modern woman would probably leave her husband, Captain Alving to get a substantial amount of money as alimony from him. Ibsen fosters the matter of morally emptiness and hollowness of traditional system and order through different dialogue of Mrs. Alving. She is the representative of her society. He creates an image of prevailing filthy hypocrisy with great anger under the concealment of human attitude of matrimonial relationship and family life of the 19th century bourgeois society and culture in Scandinavia. In his notes made for Ghosts, Ibsen has focused on sex and marriage problems as stated below:

The play is to be a picture of life. Belief undermined [...] marriage for external reasons, even when these are religious or moral, brings a Nemesis upon the offering [...]. These women of the present day, illused as daughters, as sisters, as wives, not educated according to their gifts, prevented from following their inclination, deprived of inheritance, embittered in temper - it is these who furnish the mothers of the new generation [...] [5].

Ibsen draws attention on the pitiable conditions of women. $\mathrm{He}$ wants to make women conscious of duties and responsibilities as mother, daughter, sister, and wife. They are ill-treated, deprived of basic human needs and rights. He also emphasizes on women's contribution to build up a new generation. Actually, the play, Ghosts is first planned as an attack upon marriage, in answer to the question of critics of $A$ Doll's House. Those who bitterly attacked Ghosts did on the ground of what they considered to be destructive central theme by destroying the concept of the loyalty of wife in marital relationship and her respect for home and family life. When the play opens, we find that Oswald has just come back from Paris on learning about his father Captain Alving's death. Mrs. Alving tries to straighten the affairs of her dead husband's estate, and so, she has invited the family friend, the utterly conventional Pastor Manders to help her in the familial matters. Pastor Manders interferes on everything of the Alving Heritage. We did not see Captain Alving in flesh and blood on the stage for he already died when the play opens, but his shadow occupies a special place throughout the play. Society would consider him as one of its pillars though he was in secret, a drunkard, and a libertine. A restrictive, conventional, puritanical atmosphere of his home and immediate surroundings was responsible for his cruel attitudes. He had seduced maid servant, Johanna and got a child by her who is no other than Regina, now Mrs. Alving's maid. Mrs. Alving conceals the mysterious past for nearly twenty years. Instead of getting rid of ghosts of the past by exorcism, she, following the advice of Pastor Manders, the personification of false, conventional stupid respectability, sends her son Oswald to Parisian institution away from home, and nurtures the myth of her husband as a noble and worthy figure, suffering in silence bitter agonies of shame. But she wants to free herself of the cruel past by all means. She wants to set up an orphanage with Captain Alving's money and to pacify any rumour. But ghosts of the past cannot be buried so easily. The shadow of the past plays a dormant rule throughout the play. She finds Oswald's attraction for Regina and his wish to marry her, who is not known to him, his half-sister. Thus, the 
theme of incestuous relationship is introduced in the plot. Mrs. Alving sees the strange hold of her dissolute husband on herself even after his death in Oswald's preference for unconventional joys of life. However, she wants get rid of superstitions regarding duty and decay and braces herself to make a new beginning by the terrible denouement that her son has contracted venereal disease namely syphilis as an inheritance from his father. Oswald's brain has started to soften when the play ends, he rapidly sinks into insanity. Earlier he had extracted a promise from his mother that she would give him morpheme so that he could kill himself and escape the gruesome fate of life -in -death. Now, a silent question thrills in our mind: Does the mother give him the box of poison at the last moment? Ibsen keeps it in secret [6].

Thus Ibsen wants to focus on falsehood, and filthy image of human character and female problems. An attack on hypocrisy and falsehood has grasped women and men. For instance, we may consider the dialogue between Mrs. Alving and the Pastor on the books the former has been reading. She seems to find conformation of all things that she has been thinking of those books. Pastor Manders, on the other hand, considers such books improper reading and condemns them unread. He also justifies his action by saying:

My dear Mrs. Alving, there are many occasions in life when one must rely on the judgment of others. That is the way things are and it is good that it should be so. If it were not so, what would become of society [7].

Ibsen emphasizes male domination on women of his contemporary situations. A woman has to depend on judgments of others in a patriarchal society. A husband would be decision-maker in all important matters. On the contrary, a woman will tolerate everything imposed on her silently without any debate, or any protest.

Pastor Mander: (lowers his voice) But one does not have to talk about it, Mrs. Alving. One really does not need to account to all and sundry for what one reads and thinks within one's own four walls [7].

Pastor Manders is always in favor of law and order. He thinks that these are indispensable in life. He is found to support the traditional authority. But she wants to break all social chains and decides to lead an independent life by unveiling potentiality, psychology, radical wit and prudence. She condemns those law and order. She is tired of all cant and hypocrisy, and bursts out at one point: "Oh! That perpetual law and order! I often think that is what does all the unhappiness here in the world" [7]. Mrs. Alving hankers after a life of freedom and power on the sly. She does not want to accept such constraints imposed on her by the name of ideals. At that moment, she is found to express her melancholic moods: "Oh! Ideals! If only I weren't such a coward" [7].

Mrs. Alving's growth and development are the strongest appeal of Ibsen's Ghosts. We see her when she is a middle aged woman; her heart is battered to face the truth without any false trammels. She discovered in less than a year of married life that her husband was a rake and a libertine. Then she fled from him, and took refuge with the clergyman Pastor Manders and refused to go back to Captain Alving. But, the Pastor sent her back to her husband. Then, he tells her:

[...] But a wife is not appointed to be her husband's judge. It was your duty humbly to bear that cross which a higher will had seen fit to assign to you. But instead you rebelliously fling down that cross, abandon the erring soul you should have supported, hazard your good name, and very nearly ruin the reputations of others [7].
Mrs. Alving is viewed as inferior being to the gaze of Pastor Manders. She is compelled to accept the masculine principles. She is not appointed to be her husband's judge. So, it is her duty to tolerate social norms as imposed on her. Instead, she flings down ideals and values by giving up erring soul. Since then she remains silent for about twenty years with her dissolute husband, persuaded by Manders to shoulder the yoke of what he calls duty and obligation. Twenty years later, she confesses to Manders that her whole soul has rebelled against loathsome activities of the Alving Heritage. She has lost her faith in his doctrine. Her whole soul revolts against the traditional norms and rule.

Mrs. Alving began to look into seams of his doctrine. She wanted to pick at a single knot while she had got that undone. She also realized that it was all machine sewn. Later, when her maturity begins to grow up, she is able to realize that she is living in a false state of happiness and mind. But, she has nothing to do. She is victim of irony of fate. Her appreciation of the role of joy in one's life sets her apart from the stereotyped character of a duped wife. She recalls that as a young lieutenant her husband was brimming over with the joy of life and had a great fund of exuberant strength and vitality in him, but the society he lived in was an uncongenial one. She confesses to her son with unusual candor that she did not bring any brightness into his own home.

Ibsen did not create Mrs. Alving as a lineal character. He had no purpose to focus on the inner hollowness of obsolete matrimonial relationship through this female character. Subtle emotion and sensibility have brought about a remarkable pervasion regarding the "Joy of life" in her struggle for freedom and power. In this way, she has been depicted by Ibsen not as a flat, or a dimensional character, but as a round character whose participation we see in all matters throughout the plat-text. Her quest for life and joy adds an extra dimension to her character and lifts her from being a vehicle for the debunking of traditional values and social norms [6].

In Act II of Ghosts, we hear Mrs. Alving telling Manders that she must work her way out to attain freedom and power, she regrets her past cowardice and wants to get rid of superstitious faith. Mrs. Alving sees that Oswald is attracted by Regina, who is not known to him. She feels that joy is an important creed of life. Then she says, "Marry her, or make what arrangements you please. As long as you're honest and open about it" [7]. This quotation implies her request for her son to marry Regina. Mrs. Alving has traveled a long way mentally from her earlier stage of adhering to hypocritical canons of conventional morality. But in actual life, she is unable to express those words to her son; she is still timid. She diagnoses the reason for cowardliness; she is helpless because she cannot get rid of ghosts that haunt her. She elaborates in answer to a query of Pastor Manders:

Ghosts like, when I heard Regina and Oswald in there, it was as if I saw Ghost. I almost think, we are all Ghosts-all of us, Pastor Mander. It is not just what we have inherited from our father and mother that walk in us. It is all kinds of dead ideas and all sorts of old and obsolete beliefs. They are not alive in us; but they remain in us none the less, and we can never rid themselves of them. I only have to take a newspaper and read it; and I see ghosts between the lines. There must be ghosts all over the country. They lie as thick as grains of sand. And, we are all so horribly afraid of the light [7].

Mrs. Alving perceives ghosts at every corner of her surroundings, even in the lines of newspaper and on grains of sand. She sees the presence of ghosts throughout the country. The ghosts of the past do not permit her to pursue to the end of the creed of the joy of life either 
for herself, or for her son. She does not seem to find anything dreadful in the sexual relationship between Oswald and Regine. As she confronts Pastor Manders with this question: "Do you suppose that throughout the country there aren't plenty of married couples as closely akin as they" [6]. Here Ibsen brings the question of such unions in an unambiguous fashion. An incestuous relationship has been shown as a central theme in the play, Ghosts, and it is a brother-sister relationship instead of mother-son relationship.

According to Fergusson [8], "Oswald is the chief symbol of what Mrs. Alving is seeking; when Oswald's brain crumbles her quest ends in a horrifying catastrophe" commenting on the conclusion of Ghosts, he further adds:

Ibsen brings all of the elements of his composition together in their highest symbolic valence. The orphanage has burned to the ground; the Pastor has promised Engstrand money for his "Sailors' Home" which he plans as a brothel; Regina departs to follow her mother in the search for pleasure and money [8].

Ibsen wants to concentrate on the dirty aspect of human character of his age, portraying Manders, and Engstrand.

Mrs. Alving finds everything collapsing at the end. She is reconciled to the inevitable in spite of collapse of her dreams. She is not gripped by a sense of despair, or by a spirit of heroic fortitude. She has arrived at truth through the irreparable wreck of life. She struggles and affirms the greatness of human spirit. In this regards, we may mention the comments of John Northam:

Mrs Alving at last has been freed from the gloom of ignorance induced by convention. She sees with dreadful clarity the consequences of her subservience to public opinion. Her freedom is cheerless, but she is at last aware of stark reality, even though her awareness is achieved through tragedy[...]. Mrs. Alving imagines herself to be enlightened enough to exorcise the ghosts of past actions; but she comes at length to know the complete irrevocability of deeds done long ago [6].

This above quotation offers her gloom of ignorance imposed by the traditional authority and her conscientious effort regarding power and freedom. It also implies her tragic downfall. Standing a few steps from a shrinking son with her hands twisted in her hair, Mrs. Alving stars at him in speechless terror. She perceives the truth through the irreparable wreck of life. As her world finally collapses, she becomes aware of the superficiality of her view that she may live as though the past had never been. When she notices the physical change in Oswald she shrieks, but soon she controls her shrieks, and stares at the horrible scene in silence. She accepts the inevitable. She is defeated in her inner struggle and silent revolution due to the bondage of cruel past.

In the play, Ghosts Ibsen wants to depict a blistering criticism of society and its annihilating forces. But, it is a criticism which targets the representative of the authoritative society; and who is its one rebellious element. It is the presentation of Mrs. Alving's battle against the reactionary forces within herself that demonstrates Ibsen's insight into the psyche of the bourgeois rebel. The rebel bears a share of responsibility in respect of society which denies the truth and freedom. Mrs. Alving is a rebel who fears rebellion. The tragedy of middle class life is no slogan-dominated conclusion, no proclamation of truth and freedom, and no miracle of miracles. There is only the sun to indicate those dimensions of life which are denied to symbolize an ideal, natural way of living. So, it is a natural life that Ibsen is concerned to defend these works, where he submits society to debate. It is society which prevents natural humanity from emerging and developing.
Oswald's ideal is of a community where people find happiness by virtue of existing. These ideas are based on a positive view of people as individuals. But not as a social being, in the bourgeois society, the individual is coerced into giving up any right to be himself in any natural way.

In this way, the study focuses on alienation, power, and domination of a woman. Ibsen, as a conscious critic of his age, wants to foster alienation and feminist message of the 19th century Norwegian bourgeois system and order. He hopes to show a faithful social picture of his age by creating male and female characters. Ibsen prioritizes on a woman's character, Mrs. Alving who is devoted to dominating the whole family to regain her power and freedom. Love and affection touches her heart in a state of dilemma and alienation, though she is confined to familial duty and responsibility, which is attributed on her by the patriarchy. Most of Ibsen's women suffer from an inferiority complex, including Mrs. Alving. Again some of them are found to live without family and husband, for instance: Regina as well as Johanna in the play, Ghosts.

This study shed a light on Mrs. Alving as a domineering and powerful woman of Ibsen. Mrs. Alving, living in the Alving Heritage, is alienated from happiness and peace. She always leads her life in a state of dilemma round the play. To hold her power and domination in the Alving Heritage, she sends her only son Oswald away from home so that he cannot know the true identity of his father Captain Alving. But, both father and son fall victim of irony of fate, and the whole Alving Heritage is destructed at one stage. For this purpose, it makes use of a lonely struggle for freedom, salvation and power of a woman, like Mrs. Alving from the bondage of the cruel past for investigating feminist and social issues of Ibsen's age.

\section{Feminist and Social Impact on Susan and God}

In the play, Susan and God, Crothers wants to show Susan Trexel as a self-identity and freedom loving woman who is alienated from her husband, Barrie and daughter, Blossom, because her husband is a drunkard that she does not like and then she leaves them. In fact, she wants to see the unseen and to know the unknown not through the male gaze, but through her own eyes. Thus Crothers wants to demonstrate how a family is shattered and its harmony, happiness, and peace are devastated when a woman alienates herself from her family in quest of identity and autonomy. This feminist message is dramatized through Susan's character. Similarly, Ibsen wants to represent Nora of A Doll's House as a powerful woman, who alienates herself from her husband, Torvald Helmer, children, and family in search of freedom and identity. Ibsen's female character, Nora leaves her family, slamming the door behind her; she never reunites with them. On the contrary, although Susan leaves her husband and daughter, but later, she reunites with them after Barrie has given up his alcoholic attraction.

As Crothers is a representative of feminism of her age, some of her female protagonists, including Susan Trexel are symbol of new women on the center stage. Like Ibsen, Crothers focuses on society and woman. She wants to show the demand of female economic independence in order that she is no longer demeaned by marriage as her only form of financial security as a dignified, adult, and purposeful member of the social world like Ibsen's women. Crothers explores the restlessness of a woman by satirizing her involvement in a modern religious movement. She deflates Susan's religious pretensions, making them ludicrous to the audience and opens her inner attitudes towards the hollowness of religion. She portrays the conflict between Susan's 
desire to alienate herself from her family for seeking identity and freedom, but later, a conscience awakens in her psychology, and realizes that a real place is embedded in the realm of family and society [9].

Crothers not only sheds a new light on Susan's frailty for her family, but also on her husband, Barrie's weakness for drug addiction. A family reconciliation occurs only after Barrie has given up his alcoholic attraction. She emphasizes the point that male and female, husband and wife, should adhere to virtues and fundamental ethics of life. Unless a child receives love and affection from mother and father, she or he cannot find happiness in life. Only daughter, Blossom of the Trexel family is alienated herself due to unhappy situation between her parents [10].

Crothers resolves the alienation and dilemma of Susan, a restless and dissatisfied modern woman, making her mind turn into Barrie for strength and guidance and stay with her loving family. She investigates the consequences that a woman exercises her new gained freedom and hope of light. By reflecting the disordered social and family life of the modern age, Crothers feels the necessity for a return to the basic values in social life. She also realizes that it is the duty and responsibility of an individual to strengthen him /her first rather than work for a revolutionary change in the broader sphere of the world. She wants to imply that individual changes put together in a similar change all over the world. She realizes that a woman can find happiness in home, surrounded by a truthful and loving husband and adoring children.

Lady Wiggam gives Susan ammunition for her fight to leave her family life. She tells Susan, "God is working through you to reach thousands of souls. You mustn't limit it to one man and one child" [11]. Susan decides that she never becomes a home sick woman. She wants tobe a complete human being; she wants to acquire radical ideas and thoughts through her participation in the Wiggam's Movement. She does not remain an idle woman like a frog, living in a small pond. In this regard, a maxim can be remembered: "Young men of village are just like a frog." However, Crothers expresses that salvation is not visible and cannot be regained for it takes an effort to have a deeper understanding of one's own inner self. She focuses on the ground that both male and female must accept virtues and the basic values of life. Only then it becomes possible for the family to live in peace and happiness. She resolves Susan's dilemma, a restless and revolutionary modern woman, making her turn to her husband for power and guidance with her home loving mind [12].

Crothers, like Ibsen, wants to make women conscious of their society concerning rights and suffragettes, portraying the character of Susan Trexel. She has created this character as a representative of the 20th century American society. To establish her power, freedom, religion, and identity in the patriarchal society; she goes beyond her family, and stays in England; she gathers new experiences and knowledge of society, culture, and community; then she applies them in her own practical life; she hits upon a plan to make a reconciliation with her husband.

Moreover, Susan has a firm faith in Christianity; she sees God's mercy in everything; she guesses that due to the kindness of God, she has "reunited" with her family, husband, and daughter. Thus Crothers wants to focus on religion and morality through creating the female protagonist, Susan.

From the discussion made above, we can realize that Crothers focuses feminist concerns on male-female interactions, representing alienation in attitudes and values among women. She wants to reflect women's perfect social circumstances as well as personal contradictory attitudes, as they become professionals and assume the roles assigned to men. She also emphasizes the importance of power and freedom and assertion of woman's rights to combine an identity with the fulfilling domestic life. She aims to look at the sketch of marriage, career, love, motherhood, and relations between sexes in life. The tension, between women's increasing awareness as a human being and man's desire to maintain status quo, is noticed in her plays. Although her literary works are clear and provocative expressions of sympathy for the challenges of women in confronting and presenting women's boldness and originality, her work cannot be easily characterized politically. Her free-spirited women revert to the traditional roles, especially when there is the anxiety of losing a man whom they love most. She records a sense of disillusionment with the movement and a tendency to blame it on deficiencies in the emotional life. But she has written in a period of rapid social change, as if she knew the situation very well.

\section{Nora Helmer, Mrs. Alving, and Susan Trexel}

In this study, there is a comparative study among Susan, Nora, and Mrs. Alving. All women are the representative of the age; they want to have power, freedom, self-identity, and domination through breaking the patriarchal shackles of cruelty. It exposes that Susan wants to break all sorts of traditional rules and custom through participating in the Wiggam's Movement. She gathers new experiences, radical thoughts, and ideas with the help of Wiggam, the founder of the movement. She reunites with her husband, Barrie and daughter, Blossom, getting new ideas and knowledge from the movement. In the dramatic device, Crothers develops the plot-construction in making a happy union between husband and wife. Moreover, it highlights Nora's treatment of society and family. Like Susan, she wants freedom and power, leaving her husband and children, slamming the door behind her, which still echoes into our ear. She never reunites with her family; Ibsen wants to focus on the women's situations of his age through creating the character of Nora. Furthermore, it sheds a light on Mrs. Alving's attitudes towards her society. She is the round character throughout the play, Ghosts. It is Ibsen who has given woman a vigorous and strong voice, creating this female character. She is eminent in merit, intelligence, firmness, and integrity, in comparison with the male attitude. It is widely believed that the play, Ghosts, deals with social conflict, dilemma of freedom and necessity, marriage problem, unwed motherhood and divorce, career and family, freedom and fairness in expression of salvation, vicissitudes of human life, universal rights, and suffrages of woman in the modern society. Ibsen's woman is excited in sexuality, self-conceited in appearance, and agitation caused by the demand of the bourgeois society. Ibsen wants to show how a woman is victim of sacrifice in spreading predominance of power and freedom in the traditional authority. He is a forerunner in exploring the notion of woman's self in gendered relationship. He creates an array of interesting female character in a predominantly male society. In answer to the question of the critics, including Mary Magdalum, his step mother-in-law, Ibsen writes this play; and therefore, he does not let Mrs. Alving leave her family.

Moreover, if we investigate the plays of Ibsen, we can learn that most of his women's characters, including, Nora Helmer and Mrs. Alving have no faith in Christian religion and morality. His women are far away from religion. On the contrary, if we examine Crothers' play, Susan and God, we will realize that Susan has a firm faith in God; she reunites with her husband due to her perfect confidence in religion and 
Citation: Hossain MA (2016) Influence of Henrik Ibsen on the Social Drama of Rachel Crothers. Arts Social Sci J 7: 179. doi: 10.4172/2151-6200.1000179

Page 7 of 7

morality. Although Ibsen has a mystic attitude towards religion, he feels alienation about religion. He feels loneliness and empty in himself. When his physical condition is very worse, and he is about to die, one of his priest friend requests him tobe Christianized, then the playwright replies that it is his personal concern. But Crothers, portraying her women's characters, wants to focus on the moral and religious issues. In this way, this study would like to show similarities and differences between Ibsen and Crothers. In fact, they want to focus on feminist message and social reality of their age through portraying the powerful women, including Susan, Nora, and Mrs. Alving. Reading her biography of Crothers, we can learn that she herself acknowledges that she has followed Ibsen's social and feminist themes in writing her plays. Thus, this study attempts to look at the impact of Ibsen on Crothers through the parallel feminist and social themes.

\section{Conclusion}

The researcher is of the view that Ibsen's and Crothers' plays contribute to the literary field, portraying powerful women who survive and exert their presence in today's society in different ways. Through word and action, each of women's characters appears as representative of the 21st century. Both Ibsen and Crothers have given female characters distinct identities. They have brought women to the centre-stage of their plays. They have become successful to highlight the problems women face at different levels in life. They examine how women, act and react in different circumstances, suffer from social, familial, economic and political insecurities. Though they are disenfranchised of their age, they hardly try to lag behind to sacrifice themselves for achieving identity, freedom, power, rights, and suffragettes. They appear to be powerful, adamant, vocal, and radical in the world-view.

\section{References}

1. Ibsen H, Watts P (1965) The League of Youth, A Doll's House, The Lady from the Sea., Penguin Books, London.

2. Crothers R (1938) Susan and God. Random House, New York.

3. Burke S (1996) American Feminist Playwrights: A Critical History. Twanye Publishers, New York.

4. Bandyopadhyay K (2002) Conflicting Senses of 'Power' in "A Doll's House" and Proposal for an Alternative Title. International Ibsen Conference Con Kamakuddin Nilu Dhaka: Asian for Asian Theatre pp: 75-91.

5. Saether A (1997) Female Expectations and Male Ambitions in Ibsen's Late Dramas. Centre for Asian Theatre pp: 34-35.

6. Chowdhury K (1978) Ibsen's Ghosts: A Brief Critical Study. Dacca University Studies Ed Serajul Islam, Dacca pp: 1-13.

7. Kushwaha MS (1989) Ghosts by Henrik Ibsen. Macmillan India Limited, Kolkata \& New Delhi.

8. Fergusson F (1950) The Idea of a Theatre. Folger Shakespeare Library, New York.

9. Friedman S (1984) Feminism as Theme in Twentieth-Century American Women's Drama. American studies p: 25.

10. Sai V (2007) A Woman's Dilemma: A Study of Rachel Crothers' Susan and God. The Indian Review of World Literature in English.

11. Gottlieb LC (1979) Rachel Crothers. Twane Publishers, Boston.

12. Suriakumary M (2014) Empowerment of New Women in Rachel Crothers Selected Plays. International Journal on Studies in English Language and Literature (IJSELL) 2: 63-67. 